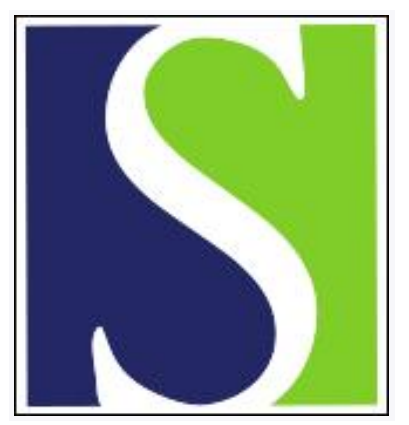

Scand J Work Environ Health 2005;31(2):108-114

https://doi.org/10.5271/sjweh.857

Issue date: Apr 2005

Time to pregnancy among Danish laboratory technicians who were a part of the National Birth Cohort

by Zhu JL, Knudsen LE, Nybo Andersen A-M, Hjollund NH, Olsen J

Affiliation: The Danish Epidemiology Science Centre, Vennelyst Boulevard 6, DK 8000 Aarhus C, Denmark. zjl@soci.au.dk

Key terms: Denmark; exposure; fecundability; fecundity; female; laboratory technician; national birth cohort; time to pregnancy

This article in PubMed: www.ncbi.nlm.nih.gov/pubmed/15864904 


\title{
Time to pregnancy among Danish laboratory technicians who were a part of the National Birth Cohort
}

\author{
by Jin Liang Zhu, MSc, ${ }^{1}$ Lisbeth E Knudsen, PhD, ${ }^{2}$ Anne-Marie Nybo Andersen, PhD, ${ }^{3}$ Niels H Hjollund, \\ $P h D,{ }^{4}$ Jørn Olsen, $P h D^{1}$
}

Zhu JL, Knudsen LE, Nybo Andersen A-M, Hjollund NH, Olsen J. Time to pregnancy among Danish laboratory technicians who were a part of the National Birth Cohort. Scand J Work Environ Health 2005;31(2):108-114.

\begin{abstract}
Objectives The Danish National Birth Cohort was used to examine whether laboratory work was associated with reduced fecundity.

Methods Self-reported data on laboratory work and waiting time to pregnancy $(0-2,3-5,6-12$ and $>12$ months) were used for 829 female laboratory technicians interviewed in 1997-2003. Altogether 6250 female teachers formed the reference group. A discrete-time survival analysis with a complementary log-log link was applied to estimate the fecundability ratio between the exposed and unexposed women, with adjustment for maternal age, gravidity, smoking, prepregnancy body mass index, and paternal job.

Results No difference in time to pregnancy was found between the laboratory technicians and teachers or between the laboratory technicians with different exposures. The adjusted fecundability ratio for the laboratory technicians was 0.94 [95\% confidence interval (95\% CI) 0.86-1.02] for all pregnancies and 0.98 (95\% CI 0.861.13 ) for first pregnancies. A healthy worker effect was found for the laboratory technicians working with the work processes under study.

Conclusions The results do not suggest that laboratory work in Denmark at present impairs female fecundity.
\end{abstract}

Key terms fecundability; fecundity; female exposure.

Work with chemicals in general, and laboratory work in particular, has, in some epidemiologic studies, shown high risks for adverse pregnancy outcomes (eg, spontaneous abortion, malformation, preterm birth, and reduced fecundity) (1-4). Laboratory work has also been associated with an increased risk of lymphatic and hematopoietic neoplasm, brain tumor, and breast cancer (5, $6)$. In other studies, the risk of spontaneous abortion or malformation was not increased $(7,8)$. The inconsistent results may reflect differences in exposures and work conditions, methodological shortcomings, or the use of underpowered studies $(9,10)$.

Time to pregnancy has become the most widely used estimate of fecundity in occupational reproductive studies in the past few decades (11-16). Time to pregnancy is easy to measure, and it can be measured with high validity $(17,18)$. This study aimed at examining whether laboratory work was associated with reduced fecundity, as measured by time to pregnancy.

\section{Study population and methods}

\section{Study population}

The study was carried out within the Danish National Birth Cohort, which has been described in detail elsewhere $(19,20)$. In short, $30-40 \%$ of all pregnant women were enrolled in the cohort in Denmark during the study period (19). From June 1997 to February 2003, a total of 88915 pregnancies were included in the first of four telephone interviews as part of the cohort data collection. We identified 1069 pregnancies of laboratory technicians who had only one job at the time of the

The Danish Epidemiology Science Centre, University of Aarhus, Aarhus, Denmark.

2 Department of Environmental and Occupational Health, Institute of Public Health, University of Copenhagen, Denmark.

3 Department of Social Medicine, Institute of Public Health, University of Copenhagen, Denmark.

4 Department of Occupational Medicine, Aarhus University Hospital, Aarhus, Denmark.

Correspondence to: Dr JL Zhu, The Danish Epidemiology Science Centre, Vennelyst Boulevard 6, DK 8000 Aarhus C, Denmark. [E-mail: zjl@soci.au.dk] 
interview and worked in laboratories of hospitals, universities, the medical industry, food industry, or public services. We excluded pregnancies of women with endometriosis, ovarian or cervical cancer, and pregnancies that were unplanned or partly planned. If a woman provided more than one pregnancy in the study period, we excluded the subsequent ones. We ended up with 829 pregnancies of laboratory technicians that were eligible for the analysis (table 1). Using the same exclusion criteria, we identified 6250 pregnancies of teachers for reference (table 1). Teachers have a similar educational background but no occupational exposure to chemicals or radioactive agents. The characteristics of the participants are shown in table 2. The laboratory technicians were younger and more often nonsmokers than the teachers. The laboratory technicians and teachers had been similarly treated for infertility $(9.8 \%$ and $8.2 \%$, respectively) and had comparative histories of spontaneous abortion (29.3\% and $31.1 \%$, respectively).

\section{Exposure assessment}

At gestational weeks 12-25 (median: week 17) the laboratory technicians were asked about their laboratory work processes during pregnancy and 3 months before the pregnancy. They were asked about the frequencies of these procedures and implementation of protective measures at work. The questions on laboratory work were identical to questions used in a previous Danish survey of industrial technicians in $1980(21,22)$. The job-exposure matrix of $15 \times 7 \times 3$ exposure levels that we used (appendix) was also designed in 1980 (22), but it was re-evaluated in 2003 and considered appropriate, except that currently there was no exposure to isotopes for the isolation of ribonucleic acid (RNA) or deoxyribonucleic acid (DNA) from tissues and cultures (Knudsen, personal communication). We used an exposure index (EI) for each exposure, which was calculated as follows: $\mathrm{EI}=\mathrm{EL} \times \mathrm{F}$, where $\mathrm{EL}=$ exposure level (appendix), low $=1$, medium $=2$, and high $=3 ; \mathrm{F}=$ frequency of work contacts, everyday $=4$, several times a week $=3$, several days a month $=2$, and more rarely $=$ 1 . We then grouped them into two groups of $1-5$ and $\geq 6$, according to the frequencies of the exposure index.

\section{Measurement of outcome}

Time to pregnancy was recorded in the interview according to the following questions: "How long did you try to become pregnant, before you succeeded? 0-2 months, 3-5 months, $6-12$ months or $>12$ months?" In addition, the woman was asked if the pregnancy was planned, partly planned, or not planned. Only planned pregnancies were included in the analysis.

\section{Statistical analysis}

Fecundability ratios were calculated using a discretetime survival analysis with a complementary log-log link (23) when the laboratory technicians were compared with the teachers or when the exposed were compared with the unexposed within the group of laboratory technicians. When comparisons were made between the laboratory technicians, those who were not exposed to one work process could be exposed to other work processes. Time to pregnancy in our study was measured in four intervals. We defined fecundability as the probability to conceive at one time of the month (instead of a menstrual cycle), conditionally depending on the fact that the women were not pregnant in the previous

Table 1. Exclusion criteria used for the laboratory technicians and teachers.

\begin{tabular}{lrrrrrr}
\hline Pregnancy & \multicolumn{2}{c}{$\begin{array}{c}\text { Laboratory } \\
\text { technicians }\end{array}$} & & \multicolumn{2}{c}{ Teachers } \\
\cline { 2 - 3 } \cline { 5 - 6 } \cline { 5 - 6 } & $\mathrm{N}$ & $\%$ & & $\mathrm{~N}$ & $\%$ \\
\hline Women with one job & 1069 & 100.0 & & 8461 & 100.0 \\
Second or third pregnancy a & 42 & 3.9 & & 397 & 4.7 \\
Endometriosis & 4 & 0.4 & & 26 & 0.3 \\
Ovarian or cervical cancer & - & 0.0 & & 2 & 0.0 \\
Unplanned & 91 & 8.5 & & 1005 & 11.9 \\
Partly planned & 103 & 9.6 & & 781 & 9.2 \\
Final study pregnancies & 829 & 77.5 & & 6250 & 73.9 \\
\hline
\end{tabular}

${ }^{\mathrm{a} A}$ woman contributed two or three pregnancies during the study period.

Table 2. Characteristics of the laboratory technicians and teachers.

\begin{tabular}{|c|c|c|c|c|}
\hline \multirow[t]{2}{*}{ Characteristic } & \multicolumn{2}{|c|}{$\begin{array}{l}\text { Laboratory } \\
\text { technicians }\end{array}$} & \multicolumn{2}{|c|}{ Teachers } \\
\hline & N & $\%$ & N & $\%$ \\
\hline \multicolumn{5}{|l|}{ Maternal age } \\
\hline $\begin{array}{l}<30 \text { years } \\
30-34 \text { years } \\
\geq 35 \text { years }\end{array}$ & $\begin{array}{r}442 \\
316 \\
71\end{array}$ & $\begin{array}{r}53.3 \\
38.1 \\
8.6\end{array}$ & $\begin{array}{r}3080 \\
2377 \\
793\end{array}$ & $\begin{array}{l}49.3 \\
38.0 \\
12.7\end{array}$ \\
\hline \multicolumn{5}{|l|}{ Gravidity } \\
\hline $\begin{array}{l}0 \\
\geq 1 \\
\text { Missing }\end{array}$ & $\begin{array}{r}327 \\
502 \\
-\end{array}$ & $\begin{array}{r}39.4 \\
60.6 \\
0.0\end{array}$ & $\begin{array}{r}2313 \\
3934 \\
3\end{array}$ & $\begin{array}{r}37.0 \\
62.9 \\
0.0\end{array}$ \\
\hline \multicolumn{5}{|l|}{ Smoking } \\
\hline $\begin{array}{l}\text { Yes } \\
\text { No } \\
\text { Missing }\end{array}$ & $\begin{array}{r}115 \\
714 \\
-\end{array}$ & $\begin{array}{r}13.9 \\
86.1 \\
0.0\end{array}$ & $\begin{array}{r}1258 \\
4990 \\
2\end{array}$ & $\begin{array}{r}20.1 \\
79.8 \\
0.0\end{array}$ \\
\hline \multicolumn{5}{|c|}{ Prepregnancy body mass index } \\
\hline $\begin{array}{l}<18.5 \mathrm{~kg} / \mathrm{m}^{2} \\
18.5-30 \mathrm{~kg} / \mathrm{m}^{2} \\
>30 \mathrm{~kg} / \mathrm{m}^{2} \\
\text { Missing }\end{array}$ & $\begin{array}{r}32 \\
734 \\
52 \\
11\end{array}$ & $\begin{array}{r}3.9 \\
88.5 \\
6.3 \\
1.3\end{array}$ & $\begin{array}{r}157 \\
5499 \\
511 \\
83\end{array}$ & $\begin{array}{r}2.5 \\
88.0 \\
8.2 \\
1.3\end{array}$ \\
\hline \multicolumn{5}{|l|}{ Paternal job } \\
\hline $\begin{array}{l}\text { Laboratory } \\
\text { Nonlaboratory } \\
\text { Unemployed } \\
\text { Missing }\end{array}$ & $\begin{array}{r}51 \\
638 \\
39 \\
101\end{array}$ & $\begin{array}{r}6.2 \\
77.0 \\
4.7 \\
12.2\end{array}$ & $\begin{array}{r}140 \\
5366 \\
518 \\
226\end{array}$ & $\begin{array}{r}2.2 \\
85.9 \\
8.3 \\
3.6\end{array}$ \\
\hline
\end{tabular}


interval and that they did get pregnant. We broke down individual time to pregnancy into a set of intervals that were treated as distinct observations. After pooling these observations, the next step was to estimate a regression model with a "cloglog" link in STATA (Stata Corp, College Station, TX, USA) with a variable to indicate the interval fitting into the model together with covariates.

Potential confounders included maternal age at conception, gravidity (pregnancy number), prepregnancy body mass index, smoking, paternal job, and alcohol consumption. Variables were kept in the model if excluding them from the full model changed the effect measure by $\geq 5 \%$. Alcohol consumption was not included in the final model because it did not change the estimates for the fecundability ratio (FR) for the laboratory technicians or for specific exposures in the laboratory. The question of whether they had smoked at any time in the first trimester was used to categorize the participants as either smokers or nonsmokers, because no information about smoking habits before pregnancy was available. Paternal job was classified according to the Danish version of the International Standard Classification of Occupation (DISCO-88) (24) into a laboratory job (2113, 2211-2213, 3111-3114, 3116, 3211-3212) and a nonlaboratory job, together with two additional categories (unemployed and missing). The analyses were performed with STATA 8.0.

\section{Results}

The laboratory technicians and teachers had a similar time to pregnancy for all pregnancies and for the first pregnancies (table 3).

Exposure to radioimmunoassay showed the lowest fecundability ratio, whereas some processes had an increased fecundability ratio for all pregnancies, first pregnancies, or both (table 4). When an exposure matrix was applied, none of the specific exposures

Table 3. Time to pregnancy and fecundability ratios (FR) for the laboratory technicians in a comparison with the teachers.

\begin{tabular}{|c|c|c|c|c|c|c|c|}
\hline & & \multicolumn{2}{|c|}{ Time to pregnancy $(\%)$} & \multirow[b]{2}{*}{$>12$ months } & \multirow[t]{2}{*}{ Crude FR } & \multirow[t]{2}{*}{ Adjusted FR ${ }^{a}$} & \multirow[t]{2}{*}{$95 \% \mathrm{Cl}$} \\
\hline & $0-2$ months & 3-5 months & 6-12 months & & & & \\
\hline \multicolumn{8}{|l|}{ All pregnancies } \\
\hline Teachers & 47.3 & 20.8 & 16.5 & 15.4 & 1.00 & 1.00 & . \\
\hline Laboratory technicians & 45.7 & 22.5 & 15.8 & 16.0 & 0.98 & 0.94 & $0.86-1.02$ \\
\hline \multicolumn{8}{|l|}{ First pregnancies } \\
\hline Teachers & 41.6 & 21.2 & 18.4 & 18.8 & 1.00 & 1.00 & . \\
\hline Laboratory technicians & 42.5 & 22.9 & 15.0 & 19.6 & 1.01 & 0.98 & $0.86-1.13$ \\
\hline
\end{tabular}

a Adjusted for maternal age, gravidity, smoking, prepregnancy body mass index, and paternal job.

Table 4. Fecundability ratios (FR) for working with specific processes among the laboratory technicians ( $N=829)$. (RNA = ribonucleic acid, DNA = deoxyribonucleic acid)

\begin{tabular}{|c|c|c|c|c|c|c|c|c|}
\hline \multirow[t]{2}{*}{ Work process } & \multicolumn{4}{|c|}{ All pregnancies } & \multicolumn{4}{|c|}{ First pregnancies } \\
\hline & $\mathrm{N}$ & $\begin{array}{c}\text { Crude } \\
\text { FR }\end{array}$ & $\begin{array}{c}\text { Adjusted } \\
\mathrm{FR}^{\mathrm{a}}\end{array}$ & $95 \% \mathrm{Cl}$ & $\mathrm{N}$ & $\begin{array}{c}\text { Crude } \\
\text { FR }\end{array}$ & $\begin{array}{c}\text { Adjusted } \\
\mathrm{FR}^{\mathrm{a}}\end{array}$ & $95 \% \mathrm{Cl}$ \\
\hline Chromatography & 163 & 1.10 & 1.16 & $0.97-1.39$ & 76 & 0.95 & 1.08 & $0.80-1.45$ \\
\hline Photometry & 203 & 1.00 & 1.04 & $0.87-1.24$ & 80 & 0.97 & 1.11 & $0.83-1.48$ \\
\hline Electrophoreses & 137 & 0.96 & 0.98 & $0.80-1.20$ & 59 & 0.90 & 1.01 & $0.73-1.39$ \\
\hline Extraction (eg, of hormones) & 105 & 1.33 & 1.35 & $1.08-1.69$ & 44 & 1.29 & 1.36 & $0.89-2.08$ \\
\hline Radiolabeling & 82 & 1.12 & 1.06 & $0.81-1.38$ & 25 & 1.07 & 1.17 & $0.64-2.13$ \\
\hline Radioimmunoassay & 50 & 0.87 & 0.85 & $0.60-1.20$ & 16 & 0.83 & 0.87 & $0.42-1.81$ \\
\hline Enzyme techniques & 239 & 1.12 & 1.14 & $0.96-1.34$ & 95 & 1.02 & 1.01 & $0.77-1.32$ \\
\hline Human blood and tissue processing & 286 & 1.06 & 1.04 & $0.89-1.22$ & 111 & 0.93 & 0.88 & $0.68-1.15$ \\
\hline Work with experimental animals & 62 & 1.09 & 1.10 & $0.81-1.49$ & 28 & 1.27 & 1.28 & $0.83-1.97$ \\
\hline Work with microorganisms & 208 & 1.12 & 1.08 & $0.91-1.29$ & 76 & 1.12 & 0.96 & $0.70-1.31$ \\
\hline Preparation of slides & 177 & 1.27 & 1.26 & $1.04-1.52$ & 70 & 1.13 & 1.06 & $0.78-1.44$ \\
\hline RNA or DNA isolation & 56 & 1.28 & 1.27 & $0.91-1.78$ & 17 & 1.52 & 1.53 & $0.81-2.92$ \\
\hline Organic-chemical processes & 154 & 1.18 & 1.23 & $1.01-1.49$ & 75 & 1.12 & 1.20 & $0.89-1.61$ \\
\hline Organic synthesis & 46 & 1.24 & 1.17 & $0.86-1.59$ & 14 & 1.99 & 2.05 & $1.00-4.19$ \\
\hline Inorganic synthesis & 46 & 1.24 & 1.31 & $0.94-1.82$ & 14 & 1.68 & 2.18 & $1.35-3.52$ \\
\hline
\end{tabular}

${ }^{a}$ Adjusted for maternal age, gravidity, smoking, prepregnancy body mass index, and paternal job. 
showed a decreased fecundability ratio for all pregnancies, and the fecundability ratios were close to unity for first pregnancies (table 5).

When the 111 laboratory technicians who did not perform any of these work processes in the laboratory were used as reference, the technicians who did one or more worktasks had a high fecundability ratio [1.43, $95 \%$ confidence interval (95\% CI) 1.14-1.80]. All the fecundability ratio estimates for the specific exposures were decreased from $3 \%$ to $13 \%$ when comparisons were made with the technicians who carried out one or more of these processes but not the work process under study (and the 111 technicians who did not perform any of these work processes were excluded). None of the fecundability ratio estimates were statistically significant (FR 0.791.22 for exposures to work processes and FR 0.90-1.20 for exposures to substances) except for the extraction of hormones or fatty acids (FR 1.27, 95\% CI 1.01-1.59).

A history of spontaneous abortion was correlated with reduced fecundability (FR $0.70,95 \%$ CI $0.65-$ 0.75 ). When we included a history of spontaneous abortion in the model, the fecundability ratio estimates changed no more than $10 \%$ (data not shown). Smoking was associated with reduced fecundability (FR 0.90, 95\% CI 0.84-0.96), but we had only crude information on past smoking. When we excluded all the smokers, we obtained almost the same results as those presented (data not shown).

We obtained similar results when we excluded pregnancies with treatment for infertility, except, for first pregnancies, the laboratory technicians had an increased fecundability ratio when compared with the teachers (FR $1.18,95 \%$ CI $1.03-1.35)$.

The use of protective measures among the laboratory technicians is shown in table 6 . The technicians without the use of protective measures showed a lower fecundability ratio for those working with the preparation of slides for microscopy (FR $0.71,95 \%$ CI $0.50-1.00$, for nonusers of local exhaust ventilation and $0.60,95 \%$ CI $0.40-0.90$, for nonusers of flow-bench), or those working with inorganic synthesis (FR $0.16,95 \%$ CI $0.04-0.55$, for nonusers of local exhaust ventilation).

\section{Discussion}

We found no difference in time to pregnancy between the laboratory technicians and the teachers or between the laboratory technicians with different exposures. First

Table 5. Fecundability ratios (FR) for exposure to specific substances, according to an external exposure matrix ${ }^{\mathrm{a}}$, among the laboratory technicians $(\mathrm{N}=829)$.

\begin{tabular}{|c|c|c|c|c|c|c|c|c|}
\hline \multirow[t]{2}{*}{ Exposure index ${ }^{b}$} & \multicolumn{4}{|c|}{ All pregnancies } & \multicolumn{4}{|c|}{ First pregnancies } \\
\hline & $\mathrm{N}$ & $\begin{array}{l}\text { Crude } \\
\text { FR }\end{array}$ & $\begin{array}{c}\text { Adjusted } \\
\text { FR }^{c}\end{array}$ & $95 \% \mathrm{Cl}$ & N & $\begin{array}{l}\text { Crude } \\
\text { FR }\end{array}$ & $\begin{array}{l}\text { Adjusted } \\
\text { FR }^{\mathrm{c}}\end{array}$ & $95 \% \mathrm{Cl}$ \\
\hline \multicolumn{9}{|c|}{ Experimental animals } \\
\hline $\begin{array}{l}1-5 \\
\geq 6\end{array}$ & $\begin{array}{r}191 \\
54\end{array}$ & $\begin{array}{l}1.19 \\
1.12\end{array}$ & $\begin{array}{l}1.18 \\
1.12\end{array}$ & $\begin{array}{l}0.98-1.42 \\
0.81-1.56\end{array}$ & $\begin{array}{l}78 \\
22\end{array}$ & $\begin{array}{l}1.04 \\
1.27\end{array}$ & $\begin{array}{l}0.98 \\
1.25\end{array}$ & $\begin{array}{l}0.72-1.34 \\
0.79-1.98\end{array}$ \\
\hline \multicolumn{9}{|l|}{ Epoxy substances } \\
\hline $\begin{array}{l}1-5 \\
\geq 6\end{array}$ & $\begin{array}{r}64 \\
111\end{array}$ & $\begin{array}{l}1.30 \\
1.28\end{array}$ & $\begin{array}{l}1.27 \\
1.28\end{array}$ & $\begin{array}{l}0.94-1.71 \\
1.02-1.61\end{array}$ & $\begin{array}{l}30 \\
40\end{array}$ & $\begin{array}{l}1.31 \\
1.02\end{array}$ & $\begin{array}{l}1.43 \\
0.86\end{array}$ & $\begin{array}{l}0.91-2.24 \\
0.58-1.28\end{array}$ \\
\hline \multicolumn{9}{|l|}{ Formaldehyde } \\
\hline $\begin{array}{l}1-5 \\
\geq 6\end{array}$ & $\begin{array}{l}306 \\
185\end{array}$ & $\begin{array}{l}1.06 \\
1.30\end{array}$ & $\begin{array}{l}1.03 \\
1.26\end{array}$ & $\begin{array}{l}0.87-1.22 \\
1.03-1.54\end{array}$ & $\begin{array}{r}112 \\
74\end{array}$ & $\begin{array}{l}1.00 \\
1.18\end{array}$ & $\begin{array}{l}0.92 \\
1.03\end{array}$ & $\begin{array}{l}0.69-1.22 \\
0.74-1.43\end{array}$ \\
\hline \multicolumn{9}{|l|}{ Dyes } \\
\hline $\begin{array}{l}1-5 \\
\geq 6\end{array}$ & $\begin{array}{l}245 \\
341\end{array}$ & $\begin{array}{l}1.23 \\
1.23\end{array}$ & $\begin{array}{l}1.34 \\
1.24\end{array}$ & $\begin{array}{l}1.10-1.63 \\
1.03-1.50\end{array}$ & $\begin{array}{l}109 \\
125\end{array}$ & $\begin{array}{l}1.03 \\
1.08\end{array}$ & $\begin{array}{l}1.11 \\
1.08\end{array}$ & $\begin{array}{l}0.81-1.53 \\
0.78-1.51\end{array}$ \\
\hline \multicolumn{9}{|l|}{ Radioisotopes } \\
\hline $\begin{array}{l}1-5 \\
\geq 6\end{array}$ & $\begin{array}{l}293 \\
165\end{array}$ & $\begin{array}{l}1.11 \\
1.04\end{array}$ & $\begin{array}{l}1.14 \\
1.05\end{array}$ & $\begin{array}{l}0.96-1.36 \\
0.85-1.29\end{array}$ & $\begin{array}{r}128 \\
59\end{array}$ & $\begin{array}{l}0.95 \\
0.93\end{array}$ & $\begin{array}{l}0.97 \\
1.10\end{array}$ & $\begin{array}{l}0.74-1.28 \\
0.74-1.62\end{array}$ \\
\hline \multicolumn{9}{|l|}{ Heavy metals } \\
\hline $\begin{array}{l}1-5 \\
\geq 6\end{array}$ & $\begin{array}{r}78 \\
146\end{array}$ & $\begin{array}{l}1.17 \\
0.98\end{array}$ & $\begin{array}{l}1.22 \\
1.01\end{array}$ & $\begin{array}{l}0.94-1.58 \\
0.82-1.25\end{array}$ & $\begin{array}{l}30 \\
57\end{array}$ & $\begin{array}{l}1.37 \\
0.92\end{array}$ & $\begin{array}{l}1.65 \\
1.06\end{array}$ & $\begin{array}{l}1.16-2.35 \\
0.75-1.51\end{array}$ \\
\hline \multicolumn{9}{|l|}{ Organic solvents } \\
\hline $\begin{array}{l}1-5 \\
\geq 6\end{array}$ & $\begin{array}{l}151 \\
528\end{array}$ & $\begin{array}{l}1.23 \\
1.40\end{array}$ & $\begin{array}{l}1.27 \\
1.45\end{array}$ & $\begin{array}{l}0.97-1.65 \\
1.15-1.81\end{array}$ & $\begin{array}{r}53 \\
214\end{array}$ & $\begin{array}{l}1.04 \\
1.04\end{array}$ & $\begin{array}{l}0.97 \\
1.04\end{array}$ & $\begin{array}{l}0.63-1.49 \\
0.74-1.47\end{array}$ \\
\hline
\end{tabular}

${ }^{a}$ Refer to the appendix.

${ }^{b}$ An exposure index (EI) for each exposure was calculated as follows: $E \mathrm{EI}=\mathrm{EL} \times \mathrm{F}$, where $\mathrm{EL}=$ the exposure level (appendix), low $=1$, medium $=2$, and high $=3 ; F=$ frequency of work contacts, everyday $=4$, several times a week $=3$, several days a month $=2$, and more rarely $=1$. It was then grouped as $1-5$ and $\geq 6$.

${ }^{c}$ Adjusted for maternal age, gravidity, smoking, prepregnancy body mass index, and paternal job. 
Table 6. Use of protective measures (\%) for the work processes. (RNA = ribonucleic acid, DNA = deoxyribonucleic acid)

\begin{tabular}{|c|c|c|c|c|c|}
\hline Work process & $\begin{array}{l}\text { Number } \\
\text { of } \\
\text { women }\end{array}$ & $\begin{array}{c}\text { Local } \\
\text { exhaust } \\
\text { ventilation }\end{array}$ & $\begin{array}{l}\text { Flow- } \\
\text { bench }\end{array}$ & Glove & Mask \\
\hline Chromatography & 163 & 82.8 & 92.6 & 89.6 & 19.0 \\
\hline Photometry & 203 & 66.8 & 60.2 & 79.6 & 6.9 \\
\hline Electrophoreses & 137 & 57.7 & 70.1 & 91.2 & 7.3 \\
\hline $\begin{array}{l}\text { Extraction (eg, of } \\
\text { hormones) }\end{array}$ & 105 & 65.7 & 87.6 & 93.3 & 10.5 \\
\hline Radiolabeling & 82 & 70.4 & 64.6 & 96.3 & 11.0 \\
\hline Radioimmunoassay & 50 & 62.0 & 58.0 & 96.0 & 10.0 \\
\hline Enzyme techniques & 239 & 55.3 & 52.3 & 78.6 & 6.8 \\
\hline $\begin{array}{l}\text { Human blood and } \\
\text { tissue processing }\end{array}$ & 286 & 39.7 & 43.4 & 80.4 & 3.5 \\
\hline $\begin{array}{l}\text { Work with experi- } \\
\text { mental animals }\end{array}$ & 62 & 48.4 & 40.3 & 85.5 & 21.0 \\
\hline $\begin{array}{l}\text { Work with micro- } \\
\text { organisms }\end{array}$ & 208 & 52.7 & 64.3 & 60.6 & 6.7 \\
\hline Preparation of slides & 177 & 56.5 & 63.3 & 79.7 & 3.4 \\
\hline RNA or DNA isolation & 56 & 42.9 & 71.4 & 76.8 & 5.4 \\
\hline $\begin{array}{l}\text { Organic-chemical } \\
\text { processes }\end{array}$ & 154 & 65.6 & 94.2 & 90.9 & 14.9 \\
\hline Organic synthesis & 46 & 65.2 & 93.5 & 91.3 & 15.2 \\
\hline Inorganic synthesis & 46 & 65.2 & 91.3 & 91.3 & 15.2 \\
\hline
\end{tabular}

pregnancies even had a shorter time to pregnancy among the laboratory technicians than among teachers for pregnancies without treatment for infertility. This finding could be due to chance, or it could reflect a difference in treatment seeking for infertility.

We found that most of the laboratory technicians wore protective gloves while working. The use of local exhaust ventilation and the flow-bench depended on the work process. Fecundability among those working with the preparation of slides for microscopy or working with inorganic synthesis may depend upon the use of protective measures, but chance findings cannot be ruled out due to multiple comparisons.

A previous study from Sweden (2) showed that the fecundability of women working in a research laboratory was similar to that of the unexposed referents but that the use of solvents in laboratories was associated with reduced fecundability. The difference in the findings could reflect different exposure levels in different laboratories. The study from Sweden originated from research laboratories, while our study addressed all laboratories (ie, only a few were research laboratories).

We recruited 30-40\% of all pregnant women in Denmark to the cohort partly because only $60 \%$ of the pregnant women were invited (19). We believe that selection bias is an unlikely reason for the lack of effect, since studying determinants of fecundity was not specified as one of the aims of the cohort. This study included only women whose pregnancies survived until the first interview (about 17 gestational weeks). All the effect measures were thus based on having had a pregnancy that lasted that long. If the exposures under study led to an all-or-none effect or early fetal loss, we had no possibility of detecting such an effect. Restricting the study to surviving pregnancies may bias the results towards the null (25). Experiences so far show, however, that most environmental exposures reduce fecundity rather than cause sterility, except in a few cases (26).

We used questions (21) related to an exposure matrix developed in 1980 (22) to evaluate exposures in laboratories. The exposure quantification was adjusted to the current work situation and relied on the laboratory experience of two authors of the study with the exposure matrix (21). The exposure matrix does not include the levels of protection, and the validity of the exposure matrix has not been tested in a separate exposure study. The results for specific exposures to substances must, therefore, be interpreted with caution.

We asked about work processes 3 months before and during pregnancy. We did not have data on the work status at the start of pregnancy planning and changes in exposure over time. If women who experience unsuccessful pregnancies change jobs, the results may be biased by misclassification of work for the proper time of exposures. We believe that this is a minor problem for laboratory work as such, since we studied skilled workers who may change worktasks but hardly occupation. Avoiding specific exposures when trying to become pregnant or during pregnancy may be a response to official recommendations, and it would bias results towards low effect measures, as seen for laboratory technicians who did none of the work processes under study. Modifying occupational exposures as a function of a previous pregnancy history may, in a way, lead to an underestimation of effects among multiparous women.

Information on time to pregnancy was obtained in a telephone interview, in which the women had to recall a recent waiting time. Validation studies of time to pregnancy have shown that the recall of time to pregnancy seems accurate even over longer time periods (12, 14, $17,18)$. We asked about time to pregnancy in four categories in order to assist the women and accepted a possible minimal loss in precision estimates of the fecundability ratio (27).

Previous use of oral contraceptives can prolong time to pregnancy in the first three cycles (28). We asked the women about the use of contraceptive pills during the past 4 months before pregnancy and found that, among those who had a time to pregnancy of 0-2 months, the proportion of previous pill use for the laboratory technicians $(38.5 \%)$ was similar to that of the teachers $(36.2 \%)$. Menstrual cycle is another important factor related to women's fecundity. We found no differences in menstrual characteristics (regularity in general and regularity, strength, and duration with regard to the last menstrual period) between the laboratory technicians and the teachers. A history of spontaneous abortion may 
be related to reduced fecundity, as well as to the exposures under study $(12,29)$. However, the results did not change much (less than 10\%) with or without adjustment for a history of spontaneous abortion. Fecundity is a couple's characteristic, but we had limited information on the male partners. A paternal laboratory job was adjusted for in the analysis to control possible effects of laboratory exposures.

Initially we performed an analysis for the first half $(\mathrm{N}=40635)$ of the data available in the cohort (split-half design), and the results were similar to those presented except for women working with radioimmunoassay, which showed a longer time to pregnancy. The National Institute of Radiation Hygiene supervises the monthly exposure to radioisotopes for all Danish laboratory workers at potential risk by monitoring dosimeters worn on laboratory coats. The monitoring data did not reveal excess exposure for these technicians and thus indicated that this finding occurred by chance (Dorthe Kolbak, personal communication, http://www.sis.dk). We decided to delay publication until we received the second half ( $N=48$ 280) of the data. The finding was not replicated in the second batch and, therefore, also signified a chance association, and we now present the results for the entire data source.

Our results suggest that working in a laboratory in current work settings has little or no effect on women's fecundity.

\section{Acknowledgments}

The activities of the Danish Epidemiology Science Centre are financed by grants from the Danish National Research Foundation, and this work was also supported by the Danish Medical Research Council (grant 22-020363), the Danish Working Environmental Council, and CHILDRENGENONETWORK (QLK4-CT-2002-02198).

\section{References}

1. Wennborg H, Bonde JP, Stenbeck M, Olsen J. Adverse reproduction outcomes among employees working in biomedical research laboratories. Scand J Work Environ Health 2002; 28(1):5-11.

2. Wennborg H, Bodin L, Vainio H, Axelsson G. Solvent use and time to pregnancy among female personnel in biomedical laboratories in Sweden. Occup Environ Med 2001;58(4):22531.

3. Taskinen H, Kyyrönen P, Hemminki K, Hoikkala M, Lajunen $\mathrm{K}$, Lindbohm ML. Laboratory work and pregnancy outcome. J Occup Med 1994;36(3):311-9.

4. Hansson E, Jansa S, Wande H, Källén B, Östlund E. Pregnan- cy outcome for women working in laboratories in some of the pharmaceutical industries in Sweden. Scand J Work Environ Health 1980;6(2):131-4.

5. Burnett C, Robinson C, Walker J. Cancer mortality in health and science technicians. Am J Ind Med 1999;36(1):155-8.

6. Wennborg H, Yuen J, Axelsson G, Ahlbom A, Gustavsson P, Sasco AJ. Mortality and cancer incidence in biomedical laboratory personnel in Sweden. Am J Ind Med 1999;35(4):382-9.

7. Heidam LZ. Spontaneous abortions among laboratory workers; a follow up study. J Epidemiol Community Health 1984;38(1):36-41.

8. Olsen J. Risk of exposure to teratogens amongst laboratory staff and painters. Dan Med Bull 1983;30(1):24-8.

9. Rachet B, Partanen T, Kauppinen T, Sasco AJ. Cancer risk in laboratory workers: an emphasis on biological research. Am J Ind Med 2000;38(6):651-65.

10. Lindbohm ML. Effects of parental exposure to solvents on pregnancy outcome. J Occup Environ Med 1995;37(8):90814.

11. Rachootin P, Olsen J. Prevalence and socioeconomic correlates of subfecundity and spontaneous abortion in Denmark. Int J Epidemiol 1982;11(3):245-9.

12. Baird DD, Wilcox AJ, Weinberg CR. Use of time to pregnancy to study environmental exposures. Am J Epidemiol 1986;124(3):470-80.

13. Weinberg CR, Baird DD, Wilcox AJ. Sources of bias in studies of time to pregnancy. Stat Med 1994;13(5-7):671-81.

14. Joffe M. Time to pregnancy: a measure of reproductive function in either sex: Asclepios Project. Occup Environ Med 1997;54(5):289-95.

15. Lindbohm ML. Women's reproductive health: some recent developments in occupational epidemiology. Am J Ind Med 1999;36(1):18-24.

16. Thonneau P, Abell A, Larsen SB, Bonde JP, Joffe M, Clavert A, et al. Effects of pesticide exposure on time to pregnancy: results of a multicenter study in France and Denmark. Am J Epidemiol 1999;150(2):157-63.

17. Joffe M, Villard L, Li Z, Plowman R, Vessey M. A time to pregnancy questionnaire designed for long term recall: validity in Oxford, England. J Epidemiol Community Health 1995;49(3):314-9.

18. Joffe M. Methods for obtaining valid data on time to pregnancy among men and women. Scand J Work Environ Health 1999;25 Suppl 1:8-9.

19. Olsen J, Melbye M, Olsen SF, Sørensen TI, Aaby P, Nybo Andersen AM, et al. The Danish National Birth Cohort-its background, structure and aim. Scand J Public Health 2001;29(4):300-7.

20. Juhl M, Nybo Andersen AM, Grønbæk M, Olsen J. Moderate alcohol consumption and waiting time to pregnancy. Hum Reprod 2001;16(12):2705-9.

21. Knudsen LE, Vogel U. Laboratoriekemikalier og laboratoriesikkerhed [Laboratory chemicals and laboratory safety]. In: Midtgaard U, Simonsen L, Knudsen LE, editors. Kemikalier og produkter i arbejdsmiljøet, bind II [Chemicals and products in working environment, part II]. Copenhagen: Arbejdsmiljøinstituttet; 2000.

22. Hvid H, Banke O, Knudsen LE, Møller CD, Olsen JH, Pedersen PK, et al. Industrilaboranters arbejdsmiljø: resultater fra en spørgeskemaunders $\varnothing$ gelse [Working environment in industrial laboratory. results from a questionnaire survey]. Copenhagen: Department of Sociology, University of Copenhagen; 1985.

23. Sallmén M, Lindbohm ML, Anttila A, Kyyrönen P, Taskinen $\mathrm{H}$, Nykyri E, et al. Time to pregnancy among the wives of 
men exposed to organic solvents. Occup Environ Med 1998;55(1):24-30.

24. DISCO-88. Statistics Denmark's Standard Classification of Occupation. 1st ed. Copenhagen: Danmarks Statistik; 1996.

25. Sallmén M, Lindbohm ML, Nurminen M. Paternal exposure to lead and infertility. Epidemiology 2000;11(2):148-52.

26. Olsen J. Design options and sources of bias in time-to-pregnancy studies. Scand J Work Environ Health 1999;25 Suppl 1:5-7.

27. Hertz-Picciotto I, Rockhill B. Validity and efficiency of ap- proximation methods for tied survival times in Cox regression. Biometrics 1997;53(3):1151-6.

28. Linn S, Schoenbaum SC, Monson RR, Rosner B, Ryan KJ. Delay in conception for former 'pill' users. J Am Med Assoc 1982;247(5):629-32.

29. Olsen J. Options in making use of pregnancy history in planning and analysing studies of reproductive failure. J Epidemiol Community Health 1994;48(2):171-4.

Received for publication: 7 April 2004

\section{Appendix}

\section{Exposure matrix for laboratory technicians}

( $L=$ low exposure, $M=$ medium exposure, $H=$ high exposure, $E L I S A=$ enzyme-linked immunosorbent assay, $R N A=$ ribonucleic acid, DNA = deoxyribonucleic acid)

\begin{tabular}{|c|c|c|c|c|c|c|c|}
\hline Work process & $\begin{array}{l}\text { Experimental } \\
\text { animals }\end{array}$ & $\begin{array}{c}\text { Epoxy } \\
\text { substances }\end{array}$ & $\begin{array}{c}\text { Formalde- } \\
\text { hyde }\end{array}$ & Dyes & $\begin{array}{l}\text { Radio- } \\
\text { isotopes }\end{array}$ & $\begin{array}{l}\text { Heavy } \\
\text { metals }\end{array}$ & $\begin{array}{l}\text { Organic } \\
\text { solvents }\end{array}$ \\
\hline $\begin{array}{l}\text { Chromatography: paper, thin layer, liquid, } \\
\text { high pressure, gas }\end{array}$ & & & & $\mathrm{L}$ & $\mathrm{L}$ & & $\mathrm{H}$ \\
\hline $\begin{array}{l}\text { Photometry: spectro, fluoro or atomic } \\
\text { absorption }\end{array}$ & & & & & $\mathrm{L}$ & M & M \\
\hline Electrophoreses: paper, gel, acrylamide & & & & $\mathrm{L}$ & & & M \\
\hline Extraction (eg, of hormones or fatty acids) & & & & & & & H \\
\hline Radiolabeling & & & & & H & & $\mathrm{L}$ \\
\hline Radioimmunoassay, isotope methods & $\mathrm{L}$ & & & & $\mathrm{H}$ & & $\mathrm{L}$ \\
\hline Enzyme techniques (eg, ELISA, etc) & & & & $\mathrm{L}$ & L & & \\
\hline Human blood and tissue processing & & & $\mathrm{L}$ & & & & $\mathrm{L}$ \\
\hline Work with experimental animals & $\mathrm{H}$ & & $\mathrm{L}$ & & & & L \\
\hline Work with microorganisms & & & L & M & & & L \\
\hline Preparation of slides for microscopy & L & M & M & $\mathrm{H}$ & & & H \\
\hline $\begin{array}{l}\text { Isolation of RNA or DNA from tissues and } \\
\text { cultures }\end{array}$ & & & & L & & & L \\
\hline $\begin{array}{l}\text { Organic-chemical processes (eg, evaporation, } \\
\text { filtration, extraction, distillation, crystallization) }\end{array}$ & & & & & & & $\mathrm{H}$ \\
\hline Organic synthesis & & & & $\mathrm{L}$ & & & $\mathrm{H}$ \\
\hline Inorganic synthesis & & & & $\mathrm{L}$ & & M & L \\
\hline
\end{tabular}

